\title{
California mealybugs can spread grapevine leafroll disease
}

Deborah A. Golino

Susan T. Sim

Raymond Gill

Adib Rowhani

\section{UC Davis's Foundation Plant Materials Service (FPMS) maintains the disease-tested, professionally identified collection of grape scion and rootstock varieties, which is the core of the California Grapevine Registration and Certification Program. In 1992, newly developed serological testing techniques revealed the presence of grapevine} leafroll-associated viruses (GLRaVs) in previously healthy vines in an older foundation propagating block, indicating active and recent virus spread. FPMS responded by increasing isolation distances and implementing a comprehensive virus screening program using the new methodology. The critical problem was the lack of information on leafroll virus epidemiology. When the distribution of infected plants in the old vineyard was mapped, new infections were frequently adjacent to known diseased grapevines. This study examined the ability of mealybugs, a putative leafroll vector, to transmit this group of viruses. We were able to confirm that four species found in California obscure, longtailed, citrus and grape mealybug - can transmit GLRaV-3 isolates: This is the first experimental evidence of grapevine leafroll virus transmission by obscure and grape mealybug. In addition, we report for the first time that GLRaV-5 can be transmitted by longtailed mealybug.

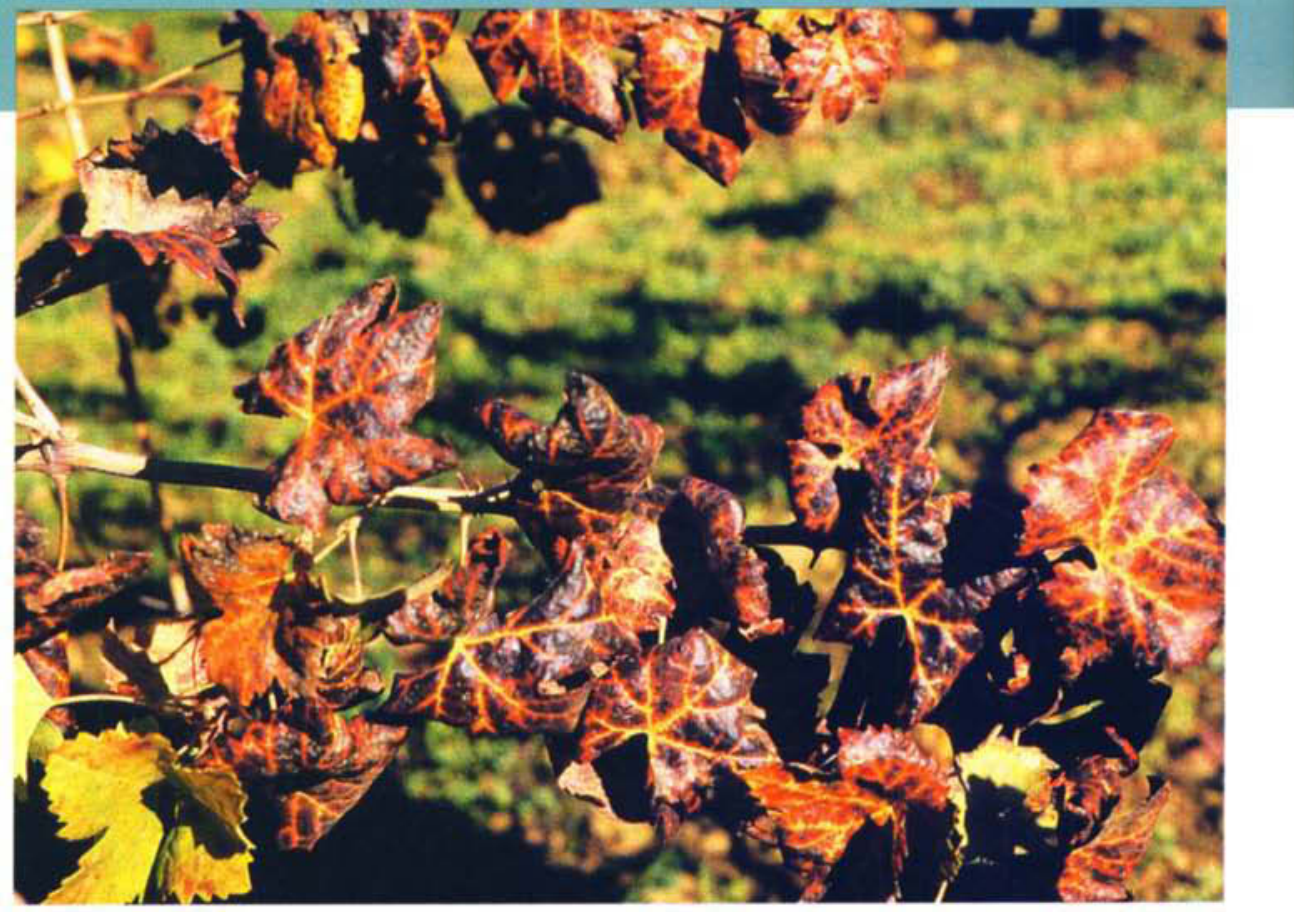

The most obvious symptom of grapevine leafroll disease, which is common in grapegrowing regions worldwide, is reddening and curling of leaves in the fall on dark-fruited varieties.

rapevine leafroll disease occurs in Jall the major grape-growing regions of the world, causing reductions in productivity and quality of both wine and table grapes. The most obvious symptom of the disease occurs in the autumn in dark-fruited varieties, which develop a strong red leaf color. In lighter fruited varieties, a general chlorosis will develop. Often, leaf margins turn under and roll downward, hence the disease name "leafroll." Growers are most concerned with reduced berry yields, delayed maturity and poor pigmentation. Some studies estimate yield losses of as much as $30 \%$ to $40 \%$. In addition, the disease agent has been implicated in certain types of graft incompatibility and young vine failure. The most successful approach to controlling leafroll disease in grapevines has been the use of disease-tested grapevine nursery stock produced through the California Grapevine Registration and Certification Program, a program administered by the California Department of Food and Agriculture.
The Foundation Plant Materials Service (FPMS) clean stock program for grapes was one of the first in the world, created during the 1950s (Alley and Golino 2000). The program was originally managed under the assumption that grapevine leafroll viruses spread only by grafting healthy stock with infected stock and did not spread naturally in vineyards (Goheen 1989). This was based on many years of observation by scientists that leafroll disease had been rarely recorded to spread between vines in California vineyards. Hence, healthy and diseased vines were planted in the same location in many of the older blocks.

In 1992, the first evidence of leafroll disease was discovered in the Foundation vineyard at UC Davis (Rowhani and Golino 1995) using the recently developed leafroll virus serological test, an enzyme-linked immunoabsorbent assay (ELISA)(Gonsalves 2000). It became clear that more research was needed on how and when leafroll was spread between grapevines. Previously, 
scientists had observed the natural spread of leafroll disease and had implicated mealybugs as putative vectors (Teliz et al. 1989; Tanne et al. 1989; Engelbrecht and Kasdorf 1990; Habili et al. 1995; Jordon et al. 1993). It was possible that this was a mechanism for spread in California vineyards as well.

We began experiments to determine whether the species of mealybug found in California vineyards could transmit domestic isolates of leafroll under experimental conditions. Four species of mealybug that are found commonly in California vineyards were selected: longtailed mealybug, Pseudococcus longispinus (Targioni-Tozzetti); obscure mealybug, Pseudococcus viburni (Signoret); grape mealybug, Pseudococcus maritimus (Ehrhorn); and citrus mealybug, Planococcus citri (Risso). Two of these four species of mealybug already had been reported to have vector potential: longtailed mealybug was reported to transmit leafroll disease agents in 1989 (Tanne et al. 1989) and citrus mealybug was reported to transmit grapevine virus $\mathrm{A}$ (Rosciglione and Castellano 1985). Neither obscure nor grape mealybug had yet been shown to transmit leafroll disease agents or any of the other grapevine closteroviruses. They were strong candidates for testing since they are widespread on grapevines in California.

\section{Establishing mealybug populations}

All mealybug species were identified by co-author Gill, pseudococcid taxonomist. Obscure and longtailed mealybug were collected from a vineyard in San Luis Obispo, with the help of UC farm advisor Mary Bianchi. Kent Daane, UC Berkeley extension assistant specialist, supplied the citrus mealybug. For all these cultures, single females were isolated and allowed to reproduce, assuring that the established culture contained only a single species. This was essential because mealybug species are often found as mixed populations, as was the case in our San Luis Obispo collection. Mealybug cultures were maintained for several years on sprouted organic potatoes in quart glass jars. They were then covered with 16XX silk-screen cloth secured with a lid band to which a caulk seal had been applied, and maintained at room temperature under fluorescent lights with a 14-hour day length and 8-hour dark period. We found that populations readily adapted to experiments on grape plants if they were reared on that host for at least a generation or so. As needed, populations were moved from potatoes to grapevines caged in greenhouses.

Grape mealybug was collected from a vineyard in Napa Valley. This species cannot be raised reliably in the laboratory; therefore, field-collected insects were used for the experiments. This population was checked to ensure that they were initially free of virus when collected from the field by screening on healthy plants and ELISA-testing of the mealybugs.

\section{Leafroll from virus collection}

Reference sources of leafroll and other grape virus diseases were established in the UC Davis grapevine virus collection (Golino 1992). This collection is essential to our studies since many grape viruses cannot easily be purified,

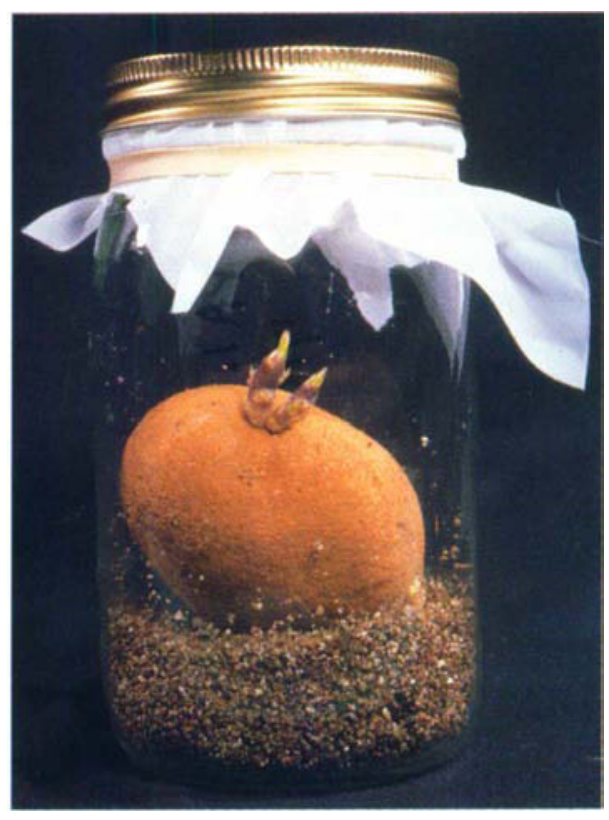

Most mealybug cultures were maintained on sprouted, organic potatoes in glass mason jars with silk-screen fabric covers.
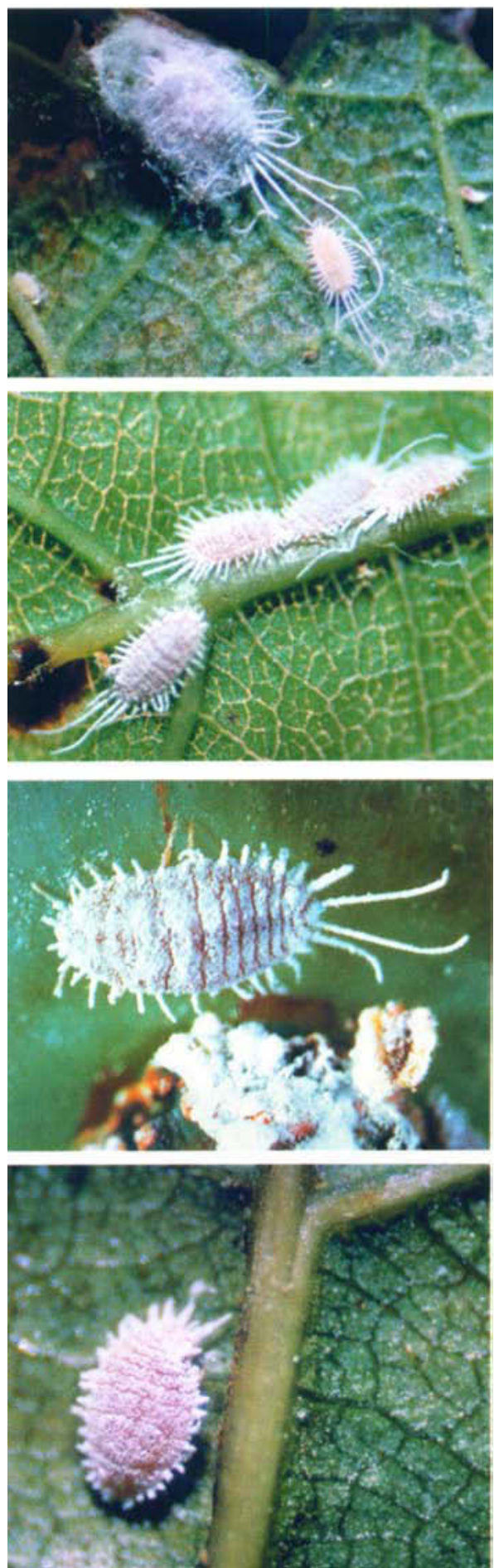

Four species of mealybug that are commonly found in California vineyards were selected for experiments on transmission of leafroll diseases: top to bottom, longtailed mealybug (female) and nymph with long, taillike filaments; obscure mealybug; grape mealybug, which is commonly found on grape berries, as shown; and citrus mealybug, with characteristic short, wedge-shaped filaments. 
TABLE 1. Virus accession number, and viruses detected in acquisition-access plants and test plants (after mealybug inoculation)

\begin{tabular}{lll}
\hline \hline & $\begin{array}{l}\text { Virusest detected in acquisition-access } \\
\text { pccession no.* }\end{array}$ & $\begin{array}{l}\text { Virus detected in } \\
\text { inoculated test plant }\end{array}$ \\
\hline LR101 & GLRaV-3, GRSPaV & GLRaV-3 \\
LR102 & GLRaV-1, GLRaV-2, GLRaV-5, GVB, GRSPaV & GLRaV-5 \\
LR106 & GLRaV-4, GRSPaV & None \\
LR109 & GLRaV-2, GLRaV-3, GFkV, GRSPaV, GVC & GLRaV-3 \\
LR114 & GLRaV-1, GLRaV-2, GVB, GRSPaV & None \\
CB100 & GLRaV-2, GVB & None \\
CB116 & GLRaV-3, GVA, GVB, GVD & GLRaV-3 \\
Healthy & None & None \\
\hline * Each acquisition-access plant was ELISA-tested before use. Test plants were ELISA-tested a minimum of four \\
times at 3, 6 and 12 months after inoculation and after the test plant had gone through at least one dormancy \\
period. A subset of plants that tested ELISA-positive was planted in a vineyard for long-term observation and \\
PCR-testing. \\
$\begin{array}{l}\text { + GLRaVs = grapevine leafroll-associated viruses (1-7); GVA, GVB, GVD = grapevine viruses A, B, D; } \\
\text { GFkV = grapevine fleck virus; GRSPaV = grapevine rupestris stem pitting-associated virus. }\end{array}$
\end{tabular}

stored or transmitted to smaller, easyto-grow plants. Leafroll disease is associated with a group of closely related viruses, all in the closterovirus group, known as grapevine leafroll-associated viruses (GLRaV), which are numbered sequentially in the order of their discovery (GLRaV-1 through -7). For our experiments, we selected the most common GLRaVs found in California, GLRaV-1, $-2,-3$ and -4 . GLRaV-2, -3 and -4 were from infected Vitis vinifera $\mathrm{cV}$. Thompson Seedless vines in the UC Davis grapevine clonal virus collection. GLRaV-1 was from infected $V$. vinifera $c v$. Pinot Noir vines in a commercial vineyard. We also tested an accession of grapevine infected with corky bark disease, another serious viral disease that some researchers believe may be mealybug transmitted. All but one of the virus accessions used were infected by more than one virus, a situation recently found to be so common in grapevines that it is difficult to find single infection sources of these viruses. At the time these experiments were initiated, the techniques available to characterize the virus profiles were still under development and it was not possible to determine whether the vines had single isolates of these diseases. We report here the results of recently completed molecular and biological screening of these virus sources (table 1).

Dormant cuttings approximately 18 inches long of each source vine were stored at $34^{\circ} \mathrm{F}$ until needed. Canes were rooted and then grown in a greenhouse until they were about 2 to 3 feet tall, ELISA-tested and used for acquisition feeding. Acquisition feeding plants also were propagated by tissue culture. Approximately 0.25 -inch-long nodes were cut from vines in the field, grown in tissue culture, and then transplanted to the greenhouse and grown to about 3 feet tall. All plants were ELISA-tested to ensure they were infected with virus.

\section{Virus detection}

The virus source plants were tested for grapevine viruses by methods including herbaceous host indicators, woody indexing, ELISA and reverse transcriptase-polymerase chain reaction (RT-PCR or PCR). Virus detection technology advanced significantly throughout the duration of these experiments, greatly improving our ability to detect and differentiate between the grapevine viruses. When our work was initiated in 1992, all virus sources were tested with herbaceous and woody indicator tests, the most reliable biological tests available at that time (Martelli 1993). By the conclusion of the project in 2001, both ELISA and PCR tests were used to better characterize our virus sources.

Herbaceous indexing involves a mechanical inoculation of susceptible herbaceous plants in the greenhouse. Woody indexing is accomplished by chip-budding virus-infected sources on susceptible cuttings of indicator grape selections and planting them in the field for 2 years of observation. Both types of tests are very sensitive in detecting the presence or absence of the disease, but do not identify the specific virus causing symptoms on the index- ing host. For example, the woody index on $V$. vinifera cv. Cabernet Franc will determine if leafroll disease is present but does not tell which virus is causing the disease. Another major limitation of the woody indicator test is the 2 years required for completion.

A special type of ELISA called $F\left(a b^{\prime}\right)_{2}$ was used to detect virus infection in test and virus acquisition plants (Rowhani 1992). A test was considered positive if the sample had an optical density of at least three times above the healthy control and was over 0.1 . Plants were observed for symptoms and tested by ELISA a minimum of three times over a 2-year period. Plants that tested ELISA-positive were established in a vineyard to document disease development.

All GLRaV source vines were screened using PCR and/or ELISA for GLRaV-1, -2, -3, -4, -5 and -7; grapevine viruses A (GVA), B (GVB) and D (GVD); grapevine fleck virus (GFkV); grapevine fanleaf virus (GFLV); tomato ringspot virus (ToRSV); arabis mosaic virus (ArMV); grapevine rupestris stem pitting-associated virus (GRSPaV); and grapevine rootstock stem lesionassociated virus (GRSLaV). PCR reactions were performed using a simplified RT-PCR technique optimized for grapevine tissue (Rowhani et al. 2000). With this new technology, it became clear that many of our virus sources were infected with more than one virus.

\section{Testing for disease transmission}

Mealybugs are difficult insects to manipulate for vector experiments. In our initial work, we found that even when individual adults - each about the size of a pinhead - were handled gently using fine brushes, transfer between plants often resulted in death of the individual, likely caused by damage to their fragile feeding stylet. We did extensive experimentation with acquisition-access feeding, transferring 
mealybugs to infected grapevines by a number of different techniques, and subsequently developed a simple and effective procedure that allowed us to screen each species for its ability to transmit the various GLRaVs. Leaf pieces were cut from one plant and placed on another. The adult insects did not move, even as the leaf dried, and they eventually died; however, the nymphal stages would move to the new plant and start feeding. A standard period of 14 days was established for acquisition and transmission based on this work. Crawlers (first instar mealybugs) were used for the acquisitionaccess feeding on virus-infected plants, then moved with leaf pieces to healthy test plants for possible transmission of the viruses.

Bulk transmission tests were performed to determine if a mealybug species could transmit a given virus type. Mixed stages of mealybug were established on virus-infected grape plants, using the method described above. The plants were placed in individual box cages, and caged plants of each virus were placed in separate walk-in cages in a greenhouse kept at $85^{\circ} \mathrm{F}$, with a 14-hour photo period. Mealybugs fed for an acquisition-access period of 2 weeks. One-node cuttings of healthy Cabernet Franc were used as inoculation test plants. Leaves of the virus-infected, mealybug-infested plants were cut into sections and arranged on test plants to allow inoculative mealybugs to crawl off as the leaf dried. Approximately 10 to 20 mealybugs were observed feeding on each test plant. The inoculation access feeding period was 2 weeks, after which plants were sprayed with the insecticide chlorpyrifos (Dursban 2E) to kill the mealybugs. Mealybugs from healthy grapes and test plants with no mealybugs were used as controls, ensuring that our insect cultures were not inoculative and that spread had not occurred by some other means under our experimental conditions.

In most tests, at least 30 plants were exposed to mealybugs that had fed on a virus-infected plant, 10 plants were exposed to mealybugs that fed on a healthy grape plant and 10 plants had no mealybug feeding. The single exception was the tests conducted with grape mealybug, which had only 10 inoculated plants, five healthy and five with no mealybug control plants. Because of the difficulty in obtaining sufficient numbers of grape mealybug, it was not tested with GLRaV- 1 and -4 sources.

We also performed tests to determine the minimum period necessary for mealybug to acquire the virus. For these experiments we used a fine brush to transfer longtailed mealybug to a grape plant infected with LR109. The mealybugs were allowed to feed for either $3,6,24,48$ or 72 hours, or 2 weeks. Fifteen to 20 insects then were transferred to each of the 10 test plants for each acquisition time period, and allowed to feed for 2 weeks to transmit the virus to the test plants.

To determine the minimum period necessary for virus transmission, longtailed mealybug that had been reared on an LR109-infected grape plant (and therefore were highly inoculative) were transferred on a fine brush in groups of 15 to 20 insects to each of 10 test plants. After allowing them to feed for a specified length of time, they were sprayed with insecticide. Time periods tested were 24,48 and 72 hours, and 7,14 and 21 days.

\section{Indicator grape test plants}

Dormant, healthy cuttings of Cabernet Franc were used for GLRaV transmission tests. Cabernet Franc is highly susceptible to leafroll disease and shows very strong symptoms of infection; it is frequently used as a biological indicator for the disease.

One-node cuttings of dormant canes were rooted in sand on warm mats and transplanted to 4 -inch pots. Plants were inoculated when they were approximately 6 inches tall with three to four leaves. They were transplanted to gallon pots after 1 month and held in an insect-proof greenhouse and screen house for testing. All plants were periodically cut back during the growing season. They were pruned to two buds during at least one dormant season.

Test plants were ELISA-tested a minimum of four times at 3,6 and 12 months after inoculation and, a final time, after the test plant had gone through at least one dormancy period. Some of the inoculated plants that became infected were planted in a vineyard for further testing. Woody indexing showed them all to be positive for leafroll disease on Cabernet Franc 
TABLE 2. Summary of virus transmission tests by California mealybugs

\begin{tabular}{ccccc}
\hline \hline $\begin{array}{c}\text { Virus } \\
\text { accession } \\
\text { no. }\end{array}$ & $\begin{array}{c}\text { Avg. \% } \\
\text { infec- }\end{array}$ & $\begin{array}{c}\text { Range } \\
\text { tion* }\end{array}$ & $\begin{array}{c}\text { No. } \\
\text { plants } \\
\text { tested } \neq\end{array}$ & $\begin{array}{c}\text { No. } \\
\text { exp. } \S\end{array}$
\end{tabular}

\section{Longtailed mealybug}

$\begin{array}{lrrrr}\text { LR101 } & 37 & 21-60 & 80 & 4 \\ \text { LR102 } & <1 & 0-10 & 120 & 4 \\ \text { LR106 } & 0 & \text { NA } 1 & 70 & 3 \\ \text { LR109 } & 35 & 10-55 & 100 & 4 \\ \text { LR114 } & 0 & \text { NA } & 110 & 3 \\ \text { CB100 } & 0 & \text { NA } & 175 & 6 \\ \text { CB116 } & \text { nt \# } & \text { nt } & \text { nt } & \text { NA } \\ \text { Healthy } & 0 & \text { NA } & 125 & \text { NA } \\ \text { Control (none) } & 0 & \text { NA } & 125 & \text { NA } \\ & & & & \\ \text { Obscure mealybug } & & & \\ \text { LR101 } & 0 & \text { NA } & 85 & 3 \\ \text { LR102 } & 0 & \text { NA } & 70 & 2 \\ \text { LR106 } & 0 & \text { NA } & 45 & 3 \\ \text { LR109 } & 19 & \text { 0-33 } & 65 & 2 \\ \text { LR114 } & 0 & \text { NA } & 35 & 2 \\ \text { CB100 } & 0 & \text { NA } & 30 & 2 \\ \text { CB116 } & \text { nt } & \text { nt } & \text { nt } & \text { NA } \\ \text { Healthy } & 0 & \text { NA } & 85 & \text { NA } \\ \text { Control (none) } & 0 & \text { NA } & 85 & \text { NA } \\ & & & & \end{array}$

\section{Grape mealybug}

\begin{tabular}{lrrrr} 
LR101 & $\mathrm{nt}$ & $\mathrm{nt}$ & $\mathrm{nt}$ & $\mathrm{nt}$ \\
LR102 & 0 & $\mathrm{NA}$ & 25 & 2 \\
LR106 & $\mathrm{nt}$ & $\mathrm{nt}$ & $\mathrm{nt}$ & $\mathrm{nt}$ \\
LR109 & 41 & $17-66$ & 23 & 2 \\
LR114 & $\mathrm{nt}$ & $\mathrm{nt}$ & $\mathrm{nt}$ & $\mathrm{nt}$ \\
CB100 & $\mathrm{nt}$ & $\mathrm{nt}$ & $\mathrm{nt}$ & $\mathrm{nt}$ \\
CB116 & 90 & $\mathrm{NA}$ & 10 & 1 \\
Healthy & 0 & $\mathrm{NA}$ & 13 & 5 \\
Control (none) & 0 & $\mathrm{NA}$ & 18 & 5 \\
& & & & \\
Citrus mealybug & & & \\
LR101 & 0 & $\mathrm{NA}$ & 40 & 2 \\
LR102 & 0 & $\mathrm{NA}$ & 40 & 2 \\
LR106 & 0 & $\mathrm{NA}$ & 80 & 4 \\
LR109 & 5 & NA & 40 & 2 \\
LR114 & 0 & NA & 40 & 2 \\
CB100 & $\mathrm{nt}$ & $\mathrm{nt}$ & $\mathrm{nt}$ & $\mathrm{nt}$ \\
CB116 & $\mathrm{nt}$ & $\mathrm{nt}$ & $\mathrm{nt}$ & $\mathrm{nt}$ \\
Healthy & 0 & NA & 40 & 12 \\
Control (none) & 0 & NA & 40 & 12 \\
\hline
\end{tabular}

- Average percent of plants positive for virus infection after inoculation using mealybugs.

t Range of transmission percentages over different experiments.

₹ Number of plants inoculated and tested.

$\$$ Number of experiments used with each mealybug and virus combination.

ก $\mathrm{NA}=$ not applicable.

\# $\mathrm{nt}=$ not tested.

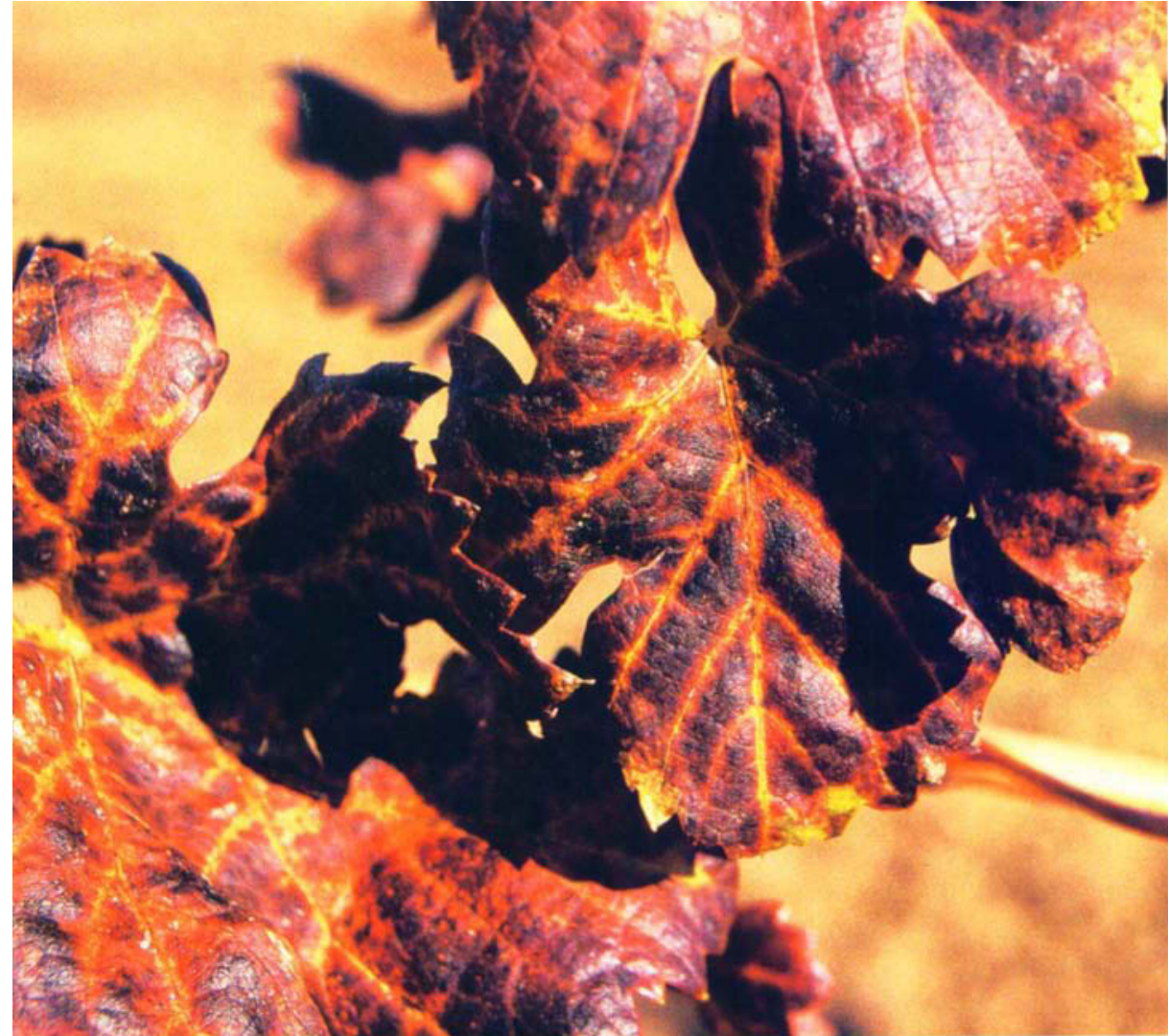

The authors determined that all four mealybug species can transmit grapevine leafroll disease via feeding. Above, 'Cabernet Franc' vines developed severe leafroll systems after infected longtailed mealybug fed on them.

and negative for other diseases on the indicators St. George, LN-33 and Kober 5BB. They were also retested by PCR for the other grapevine viruses.

\section{Mealybug spreads leafroll viruses}

We were able to determine that four California species of mealybug - obscure, longtailed, citrus and grape-can transmit California GLRaV-3 isolates (table 2). These experiments demonstrated for the first time that obscure and grape mealybug are capable of transmitting GLRaV-3 viruses. We can confirm previous reports of the ability of longtailed and citrus mealybug (Cabaleiro and Segura 1997) to transmit GLRaV-3 and establish that our experimental populations from California vineyards are competent vectors. Only one other apparent virus transmission was recorded: two Cabernet Franc vines fed upon by longtailed mealybug developed severe leafroll symptoms and PCR-testing revealed the presence of GLRaV-5. This is the first record of GLRaV-5 transmission by any vector.

Extensive screening of the test plants was unable to detect transmission of any other grapevine leafroll-associated viruses, even when inoculum sources were infected with multiple virus types. Only GLRaV-3 and GLRaV-5 were transmitted by the mealybug species and, to the limits of our detection ability, none of the other viruses present in the original virus sources were transmitted. Apparently, the mealybug acted as a filter and created single infections of GLRaV-3 and GLRaV-5. This is likely due to the specificity of virus and insect interactions of each leafroll virus type. Mealybug may never transmit other leafroll viruses, although it is difficult to draw conclusions from negative data of this nature.

The single infections we have created will prove valuable for future research. Much of the work on the effects 
of these viruses has been done with multiple infections, making it hard to determine the effect of individual viruses; these new single infections will allow research on individual viruses.

This work was conducted using laboratory populations established from a single vineyard for each of the mealybug species. In the case of grape mealybug, all the insects came from just a few vines. We would expect there to be population variation related to vector efficiency and specificity within the mealybug species. Furthermore, it was only possible to test a limited number of virus strains and types. We have demonstrated that it is possible for transmission to occur, but cannot yet comment on the variation in vector potential beyond these laboratory populations. Additional work with diverse collections is needed to generalize more broadly about the transmission biology of California populations of these species.

During our work, reports have been published confirming transmission of GLRaV-3 by the soft scale Pulvinaria vitis (Linnaeus). We now also know that GLRaV-1 is transmitted by two species of soft scale insects, but not mealybug (Martelli 2000). These two soft scale species, Parthenolecanium corni (Bouché) and Neopulvinaria innumerabilis (Rathvon), are found in California.

Our tests to determine a minimum virus-acquisition feeding period for longtailed mealybug were inconclusive; no virus transmission was observed at the shorter intervals. We believe this may have been due to the necessity of handling the fragile individual mealybugs twice to complete the experiments. The tests to determine minimum virustransmission feeding period by this species were more successful. Virus transmission occurred within 24 hours, the shortest period we tested, indicating that the minimum acquisition-feeding period is less than 1 day.

Our results clearly indicate that the obscure, longtailed, citrus or grape mealybug could have been responsible for the spread of GLRaV-3 observed at the foundation vineyard. A rigorous search in the old foundation vineyard did discover limited numbers of grape mealybug. This does not prove that mealybug was the cause of leafroll spread in the collection, but does indicate a possibility since they are present in the area.

\section{Strategies for the future}

Based on these results, it is clear that the species of mealybug found in California vineyards are capable of transmitting at least two of the viruses that cause leafroll disease, GLRaV-3 and GLRaV-5. Although documented cases of field transmission are rare, it is essential that vines in the California Grapevine Registration and Certification Program be protected from natural disease spread, both at the FPMS vineyard and at commercial nurseries producing certified stock. To ensure maximum protection of nursery stock, we recommend the implementation of greater isolation of registered plants from any potential virus source plants and control of mealybug populations in these plantings. By combining these practices with regular monitoring of registered vines and the new laboratory tests, it will be possible to produce a high-quality grapevine stock free of target viruses.

\section{D.A. Golino is Cooperative Extension} Plant Pathology Specialist, S.T. Sim is Staff Research Associate, and A. Rowhani is Plant Pathology Specialist, Department of Plant Pathology, UC Davis; and R. Gill is Senior Insect Biosystematist, Plant Pest Diagnostic Center, California Department of Food and Agriculture. The authors thank Mary Bianchi, San Luis Obispo Farm Advisor, for assistance in locating mealybug populations; Kent Daane, UC Berkeley Extension Assistant Specialist, for populations of citrus mealybug and advice on insect rearing strategies; Glen Friebertshauser, Agrianalysis, for GLRaV-1-infected cuttings; and Estelle Devevre and Jorge Jimenez for excellent technical assistance. We gratefully acknowledge financial support provided by the American Vineyard Foundation, the California Table Grape Commission, and the Fruit and Nut Tree and Grapevine Industry Advisory Board. Portions of this work have been previously published as abstracts.

\section{References}

Alley L, Golino D. 2000. The origins of the grape program at Foundation Plant Materials Service. Proc 50th Annu Am Soc Enol Viticulture meeting, Seattle, WA. Am J Enol Vitic 51:222-30

Cabaleiro C, Segura A. 1997. Field transmission of grapevine leafroll associated virus 3 (GLRaV-3) by the mealybug Planococcus citri. Plant Dis 81:283-7.

Engelbrecht DJ, Kasdorf GGF. 1990. Field spread of corky bark, fleck, leafroll and Shiraz decline diseases and associated viruses in South African grapevines. Phytolactica 22:347-54.

Goheen A. 1989. Virus diseases and vine selection. Am J Enol Vitic 40:67-72.

Golino D. 1992. The Davis grapevine virus collection. Am \& Enol Vitic 43:200-5.

Gonsalves D. 2000 . Progress towards understanding the genomic organization and expression of grapevine closteroviruses. Proc 13th International Committee on Study of Virus and Virus-like Diseases of Grapevine, Adelaide, Australia. p 6-7.

Habili N, Fazeli DF, Ewart A, et al. 1995.

Natural spread and molecular analysis of grapevine leafroll-associated virus 3 in Australia. Phytopathol 85:1418-22.

Jordan D. Peterson C, Morgan L,

Segaran A. 1993. Spread of grapevine leafroll and its associated virus in New Zealand vineyards. Proc 12th International Committee on Study of Virus and Viruslike Diseases of Grapevine, Montreauz, Switzerland. p 113-4.

Martelli GP. 1993. Graft-transmissible Diseases of Grapevines: Handbook for Detection and Diagnosis. UN FAO, Rome, Italy. 262 p.

Martelli GP. 2000. Major graft-transmissible diseases of grapevines: Nature, diagnosis and sanitation. Proc 50th Annu Am Soc Enol Viticulture meeting, Seattle, WA. Am J Enol Vitic 51:231-6.

Rosciglione B, Castellano MA. 1985. Further evidence that mealybugs can transmit grapevine virus A (GVA) to herbaceous hosts. Phytopath Medit 24:186-8.

Rowhani A. 1992. Use of $F\left(a b^{\prime}\right)_{2}$ antibody fragment in ELISA for the detection of grapevine viruses. Am J Enol Vitic 43:38-40.

Rowhani A, Biardi L, Johnson R, et al. 2000. Simplified sample preparation method and one-tube RT-PCR for grapevine viruses. Proc 13th International Committee on Study of Virus and Virus-like Diseases of the Grapevine, Adelaide, Australia. p 148

Rowhani A, Golino D. 1995. ELISA test reveals new information about leafroll disease. Cal Ag 49(1):26-9.

Tanne E, Ben-Dov Y, Raccah B. 1989 Transmission of closterovirus-like particles by mealybugs (Pseudococcidea) in Israel. Phytoparasitica 17(1):64.

Teliz D, Gonsalves D, Hu JS, Hummer DJ. 1989. Detection of grapevine leafroll associated closteroviruses in recently infected tissue in New York and spread of the disease in Mexico. Phytoparasitica 17(1):68-9. 